\title{
Irfani
}

ISSN 1907-0969 E ISSN 2442-8272

Volume 16 Nomor 1 Juni 2020

Halaman 26-45

http://journal.iaingorontalo.ac.id/index.php/ir

\section{PENINGKATAN SPIRITUALITAS MELALUI MEDIA PEMBELAJARAN INTERAKTIF PADA MATA PELAJARAN AKIDAH AKHLAK}

\author{
Seka Andrean ${ }^{1}$, M. Khusnun Niam ${ }^{2}$ \\ ${ }^{12}$ UIN Sunan Kalijaga Yogyakarta \\ email: ${ }^{1}$ sekaandrean28@gmail.com, ${ }^{2}$ moh.caknun@gmail.com
}

\begin{abstract}
ABSTRAK
Dewasa kini, dunia pendidikan telah berkembang dan maju dengan disertai masuknya hasil pemikiran dalam dunia Ilmu Pengatahuan dan Teknologi (IPTEK) yang telah mencetak beberapa alat canggih. Sehingga, memberikan dampak yang positif yakni sebagai alat yang mempermudah guru dalam menyampaikan sebuah materi dengan tidak terlalu memfokuskan pada metode tradisional. Meski demikiran, hadirnya media di dunia pendidikan hanya akan memundurkan nilai-nilai spiritual pada diri anak. Sehingga, berdampak pada hilangnya tujuan pendidikan yang membentuk manusia dengan moral agama. Artikel ini mengkaji terkait media pembelajaran interaktif dalam mata pembelajaran akidah akhlak dan implikasinya dalam peningkatan spiritualitas. Tujuan dari penelitian ini ialah untuk meningkatkan spiritualitas siswa dalam pembelajaran akidah akhlak melalui media pembelajaran interaktif. Penelitian ini merupakan penelitian kualitatif pustaka, dengan pendekatan deskriptif-analisis, yakni pendekatan yang digunakan untuk mendeksripsikan data-data yang didapat kemudian dianalisis dan disajikan dalam bentuk deskripsi. Hasil penelitian ini menunjukan bahwa media interaktif dalam pembelajaran akidah akhlak memberikan dampak positif terhadap peserta didik. Hal ini didasarkan pada pembelajaran yang tidak selalu menjadikan guru sebagai pusatnya, melainkan juga, menjadikan peserta didik sebagai pusat. Sehingga, mempengaruhi terbentuknya jiwa yang percaya diri. Selain itu, peningkatan spiritualitas dalam pembelajaran akidah akhlak yang disampaikan dengan media interaktif memberikan dampak yang baik terhadap perkembangan pola pikir, sikap dan membentuk peserta didik yang aktif juga senang akan pembelajaran akidah akhlak.
\end{abstract}

Kata Kunci : Akidah Akhlak, Media Interaktif dan Spiritualitas 


\section{Irfani}

ISSN 1907-0969 E ISSN 2442-8272

Volume 16 Nomor 1 Juni 2020

Halaman 26-45

http://journal.iaingorontalo.ac.id/index.php/ir

\section{PENDAHULUAN}

Mutu sumber daya manusia yang dimiliki suatu bangsa menjadi salah satu aspek majunya suatu bangsa tersebut. Dalam hal ini tidak bisa terlepas dari kondisi generasi muda dan fase optimisnya pada masa pendidikan dalam suatu wilayah negara. Generasi muda yang inovatif dan kreatif sebagai tongkak estafet dari pendahulu untuk kemajuan suatu bangsa. Hal tersebut tidak terlepas bagaimana peradaban terbentuk oleh generasi yang optimis membentuk suatu kemajuan, baik untuk dirinya, keluarganya, wilayahnya, bahkan negara dan bangsanya. Sehingga, tidak bisa terlepas dari energi spiritual dalam diri sebuah individu yang mendiami suatu wilayah.

Dalam sebuah negara, lazimnya kualitas pendidikan menjadi perhatian utama (main concern) bangsa-bangsa di dunia. Sejatinya, karena pentingnya pendidikan yang berkualitas untuk membentuk kualitas sumber daya manusia. Selain itu, pendidikan akan menentukan kualitas orang-orang yang menjalankan roda hukum serta mengelolah ekonomi suatu bangsa yang keduanya merupakan salah satu dasar utama kemajuan bangsa. ${ }^{1}$ Untuk hal itu, dengan mengembangkan mutu pendidikan menjadi yang berkualitas juga akan menjadikan sumber daya manusia yang berkualitas, melahirkan generasi muda seperti yang diharapkan dan dapat mendorong kemajuan suatu bangsa.

Sehubungan dengan persiapan generasi baru melalui dunia pendidikan, tentunya tidak bisa dijauhkan dari fase keprihatinan yang muncul dari berbagai dampak negatif dari kecanggihan teknologi di era disrupsi seperti sekarang ini. Hal tersebut menjadi sebab mundurnya nilai-nilai spiritual yang diselubungkan dalam pendidikan dalam rangka membentuk manusia yang sadar dalam beragama dan memiliki daya untuk membentuk peradaban yang berkarakter dan religius. Sehubungan dengan ini Ramayulis mengemukakan bahwa pendidikan Islam merupakan proses mempersiapkan manusia supaya hidup dengan sempurna dan bahagia, mencintai tanah air, tegap jasmaninya, sempurna budi pekertinya (akhlaknya), teratur pikirannya, halus perasaanya, mahir dalam pekerjaannya, manis tutur katanya, baik lisan maupun tulisan. ${ }^{2}$

Hal ini sesuai dengan apa yang disampaikan dalam Islam, bahwa pendidikan merupakan usaha menumbuhkan dan membentuk manusia muslim

${ }^{1}$ Chilmiyah Izzatul Mufidah, "Pengembangan Modul Pembelajaran Pada Kompetensi Dasar Hubungan Masyarakat Kelas X Apk 2 Di SMKN 10 Surabaya," Jurnal Pendidikan Administrasi Perkantoran (JPAP) 2, no. 2 (2014), h. 2. Lihat juga Hudaya Latuconsina, Pendidikan Kreatif: Menuju Generasi Kreatif dan Kemajuan Ekonomi Kreatif di Indonesia (Jakarta: Gramedia Pustaka Utama, 2014), h. 28.

${ }^{2}$ Heri Gunawan, Pendidikan Isalm (Bandung: Remaja Rosdakarya, 2014), h. 9. 


\section{Irfani}

ISSN 1907-0969 E ISSN 2442-8272

Volume 16 Nomor 1 Juni 2020

Halaman 26-45

http://journal.iaingorontalo.ac.id/index.php/ir

yang sepurna dari segala aspek yang bermacam-macam, seperti aspek kesehata, akal, keyakinan, kejiwaan, akhlak, kemauan, daya cipta dalam semua tingkat pertumbuhan yang disinari oleh cahaya Islam dengan metode yang terkandung di dalamnya. ${ }^{3}$ Sehingga, seharusnya kecanggihan teknologi yag terjadi di era disupsi dewasa ini menjadi modal atau alat untuk membentuk generasi baru yang memiliki karakter religius dengan spiritualitasnya dan berefek pada kesadaran pentingnya memaksimalkan daya akal.

Hal tersebut sesuai dengan perkembangan zaman pada era globalisasi saat ini pembelajaran dapat kita lakukan dengan memanfaatkan adanya perkembangan teknologi. Sejatinya, perkembangan dunia pendidikan selalu beriringan dengan perkembangan teknologi (IPTEK). Sumber daya teknologi dapat dimanfaatkan sebagai salah satu cara penggunaan teknologi dalam pendidikan yaitu memanfaatkan teknologi dalam pembuatan media pembelajaran. ${ }^{4}$ Menimbang media yang sering digunakan saat ini masih sebatas pada buku cetak. ${ }^{5}$

Namun, dalam realitas ruang publik, teknologi dijadikan sebagai akar kemunduran oleh beberapa kelompok yang masih berpegang teguh pada sistem tradisionalisme tanpa melakukan filterisasi. Hal tersebut melahirkan paradigma pada generasi baru yang akan berdampak pada kekakuan dan tidak menerima perubahan. Selain itu, hal ini juga berdampak pada pola pikir keberagamaan yang ekslusiv dan berdampak pada keresahan dalam kehidupan sosialnya. Sehingga, terbentuk generasi yang tidak mampu beradaptasi dan bahkan tidak bisa mendayakan dampak positif dari modernitas, khususnya terkait perkembangan teknologi dalam pendidikan

Bertolak pada persoalan di atas, artikel ini bertujuan mendeskripsikan, menjelaskan dan menganalisis terkait peningkatan spiritualitas dalam pendidikan melalui kemajuan teknologi yang dimanfaatkan dalam proses pembelajaran yakni menjadikannya sebagai media pembelajaran. Sehingga, dalam pembahasan artikel ini serat dengan, spiritualitas anak, media interaktif, dan pembelajaran.

\footnotetext{
${ }^{3}$ Muhammad Muntahibun Nafis, Ilmu Pendidikan Islam (Yogyakarta: Teras, 2011), h.
} 24.

${ }^{4}$ Muhammad Syazali Rubhan Masykur, Novrizal, "ePengembangan Media Pembelajaran Matematika Dengan Macromedia Flash"e, Al-Jabar: Jurnal Pendidikan Matematika, 8.2 (2017), h. 178 .

5 Heni Rodiawati And Komarudin Komarudin, "Pengembangan E-Learning Melalui Modul Interaktif Berbasis Learning Content Development System," Jurnal Tatsqif 16, no. 2 (2018), h. 172-185. 


\section{Irfani}

ISSN 1907-0969 E ISSN 2442-8272

Volume 16 Nomor 1 Juni 2020

Halaman 26-45

http://journal.iaingorontalo.ac.id/index.php/ir

\section{METODOLOGI PENELITIAN}

Penelitian ini merupakan library risearch, artinya peneltian ini dilakukan melalui penelusuran dan telaah terhadap karya-karya, baik berupa buku, jurnal, majalah, makalah serta berbagai media yang mengelola perihal topik ini. Secara garis besar, dalam penelitian library research dilakukan melalui 2 tahapan yakni reduksi (pengumpulan data) dan olah analisis. Dalam hal ini, analisis penelitian ini menggunakan pendekatan deskripsi-analisis.

\section{HASIL PENELITIAN DAN PEMBAHASAN}

\section{A. Deskripsi Hasil Penelitian}

\section{Spiritualitas Anak}

Menurut Agustian, dalam buku karya Wahyudi Siswanto yang berjudul "membentuk kecerdasan spiritual anak". Spiritual berasal dari kata spirit yang artinya murni. Apabila manusia memiliki jiwa yang jernih, maka dia akan menemukan potensi dirinya sekaligus menemukan siapa Tuhannya. ${ }^{6}$ Kata "spiritual" sendiri berasal dari kata spirit yang berarti roh. Kata ini berasal dari bahasa Latin, yakni spiritus yang berarti bernafas. Selain itu kata spiritus dapat mengandung arti al-kohol yang dimurnikan. Dengan demikian, spiritual dapat diartikan sebagai sesuatu yang murni. ${ }^{7}$ Dalam dunia modern kata spirit juga merujuk ke energy hidup dan segala sesuatu diluar tubuh fisik, termasuk pikiran, perasaan dan karakter. ${ }^{8}$

Esensi spiritualitas adalah adanya relasi, artinya memiliki kaitannya dengan hubungan seorang makhluk dengan Tuhan, dengan sesama manusia dan akam semesta. Roy F. Baumeister dan Kathleen D. Vohs dalam artikelnya The Persuit of Meabingfulness in Life, menyebutkan bahwa keterhubungan (koneksi) merupakan esensi dari makna. Demikianlah, penemuan makna hidup dan spiritualitas merupakan dua hal yang tidak bisa dipisahkan. ${ }^{9}$ Dengan modal spiritualitas, manusia mengabdi kepada Allah untuk mengelola bumi sebagai khalifah, semata untuk mencari keridhaan Allah. Target utamanya adalah menegakan keadilan, menciptakan kedamian membangun kemakmuran dengan langkah nyata. Manusia pada hakikatnya sejak lahir telah cenderung kepada fitrahnya yaitu kebaikan. Fitrah bukan berarti bersih bukan seperti yang digambarkan teori tabula rasa, yang menganggap manusia dilahirkan bagaikan

h. 11 .

${ }^{6}$ Wahyudi Siswanto, Membentuk Kecerdasan Spiritual Anak (Jakarta: Hamzah, 2010,

${ }^{7}$ Ariwibowo Suprajitno A \& Irianti E, Menyentuh Hati Menyapa Tuhan (Renungan dan Kebiasaan menuju Kecerdasan Spiritual), (Jakarta: Elex Medina Komputindo, 2010), h. Xx.

${ }^{8}$ Agus Efendi, Revolusi Kecerdasan Abad, (Bandung, Alfa Beta, 2005), h. 206.

${ }^{9}$ Ujam Jaenudin, Psikologi Transpersonal, (Bandung: Pustaka Setia, 2012), h. 196-197. 


\section{Irfani}

ISSN 1907-0969 E ISSN 2442-8272

Volume 16 Nomor 1 Juni 2020

Halaman 26-45

http://journal.iaingorontalo.ac.id/index.php/ir

kertas putih yang siap menerima warna apa saja yang digambarkan diatasnya. Sedangkan teori fitrah membawa potensi untuk menjadi baik. ${ }^{10}$

Untuk mengembangkan spiritualitas anak dapat dilakukan dalam beberapa kegiatan-kegiatan yang dalam kehidupan sehari-hari, yaitu sebagai berikut:

a. Melatih anak senang berbuat baik

Orang tua dapat melatih anak-anaknya untuk senang dalam berbuat baik sejak anak-anak masa kecil. Perbuatan baik di sini bisa jadi menurut agama dan keyakinan yang dianut oleh orang tua dan keluarga, bik menurut adat istiadat dan kebiasaan setempat, maupun ukuran baik menurut nilai-nilai kemanusiaan yang universal.

Hal yang dapat dilakukan oleh orangtua dalam melatih anak-anaknya agar senang dalam berbuat baik ini adalah memberikan pengertian tentang pentingnya perbuatan baik tersebut. Pengertian yang baik didapatkan oleh anak akan memunculkan kesadaran senang dalam melakukan perbuatan baik yang kita latihkan. ${ }^{11}$

Sebagai contoh kita melatih agar anak-anak senantiasa berbuat baik kepada Tuhan dengan taat kepada-Nya.Demikian pula dengan berbuat baik kepada sesama manusia dengan melatih anak berbuat baik tanpa mengharap imbalan, baik berupa pujian atau harapan agar orang tersebut berbuat serupa kepada kita.

b. Melatih anak senang menolong orang lain

Senang menolong orang lain perlu kita latihkan kepada anak-anak kita. Apalagi hidup di zaman modern seperti ini, yang orang-orangnya cenderung individualis dan sibuk dengan urusan masing-masing.Tidak jarang kita melihat ada seseorang yang jelas-jelas membutuhkan pertolongan, namun orang yang disekitarnya tampak cuek saja.

Sebagai orang tua bisa melatih anak-anak kita setidaknya ada tiga cara dalam menolong orang lain, yakni menolong dengan kata-kata atau nasihat, menolong dengan tenaga, dan menolong dengan barang (baik berupa makanan, obat-obatan, uang atau harta benda lainnya). Contohnya ketika teman kita mengalami kesedihan, kita dapat menolongnya dengan memberikan nasihat yang membangkitkan semangat.Contoh menolong dalam bentuk tenaga misalnya

${ }^{10}$ Baharudin, Aktualisasi Psikologi Islami, (Yogyakarta: Pustaka Pelajar, 2005), h. 199200.

11 Akhmad Muzaimmin Azzet. Mengembangkan Kecerdasan Spiritual Bagi Anak, (Yogyakarta: Katahati, 2013), h. 57. 


\section{Irfani}

ISSN 1907-0969 E ISSN 2442-8272

Volume 16 Nomor 1 Juni 2020

Halaman 26-45

http://journal.iaingorontalo.ac.id/index.php/ir

mengambilkan buku temannya yang terjatuh, menyebrangkan nenek tua dijalan, ikut memperbaiki sepeda temannya yang rusak, dan yang lainnya. ${ }^{12}$

c. Melibatkan anak-anak dalam beribadah

Libatkan anak dalam kegiatan ritual keagamaan. Kegiatan agama adalah cara praktis untuk tune in dengan sumber dari segala kekuatan. Kegiatan keagamaan tidak boleh dilakukan dengan terlalu banyak menekankan hal-hal yang formal.Berikan kepada anak-anak kita makna batiniah dari setiap kegiatan keagamaan. ${ }^{13}$

Sungguh melibatkan anak-anak dalam beribadah ini penting sekali bagi perkembangan jiwa sang anak. Bila tidak penting Nabi Muhammad Saw.bahkan sudah melarangnya demi kekhusyukan dalam beribadah. Apabila anak sejak usia dini sudah dilibatkan dalam beribadah, kecerdasan spiritualnya akan terasah dengan baik. Sebab, didalam setiap bentuk ibadah selalu terikat dengan keyakinan yang tidak kasat mata, yakni keimanan.Kekuatan keimanan inilah yang membut seseorang bisa mempunyai kecerdasan spiritual yang luar biasa. ${ }^{14}$

d. Menikmati pemandangan alam yang indah

Teknologi modern dan kehidupan urban membuat kita teraliensi dari alam kita tidak akrab lagi dengan alam. ${ }^{15}$ Alam raya yang diciptakan oleh Tuhan ini begitu luas. Bila manusia benar-benar memerhatikan alam, maka akan menimbulkan kekaguman yang luar biasa. Menikmati pemandangan alam yang indah bisa membangkitkan kekaguman jiwa terhadap sang pelukis alam, yakni Tuhan yang maha kuasa. Inilah sebabnya menikmati alam juga termasuk dalam metode meningkatkan kecerdasan spiritual anak. Oleh karena itu orangtua perlu mengajak anak-anaknya menikmati keindahan alam. Setidaknya hal ini dapat dilakukan dengan dua cara. Cara yang pertama, orang tua perlu mengajak anaknya menikmati keindahan alam disekitar tempat tinggal.Atau dengan memandang langit ditengah malam dengan melihat banyak bintang-bintang dan bulan.Yang kedua mengajak anak ke tempat yang jarang atau belum pernah dikunjungi, misalnya, orang tua mengajak anaknya berkunjung ke daerah pegunungan yang menghijau, pantai dengan laut yang membentang dan ombak-ombak. ${ }^{16}$ Dengan kedua cara tersebut setidaknya akan membuat akan terkagum dan terkesan dengan ciptaan Tuhan.

\footnotetext{
${ }^{12}$ Akhmad Muzaimmin Azzet. Mengembangkan Kecerdasan.., h. 60.

${ }^{13}$ Jalaluddin Rakhmat, SQ For Kids: Mengembangkan Kecerdasan Spiritual Anak Sejak

${ }^{14}$ Akhmad Muzaimmin Azzet. Mengembangkan Kecerdasan.., h. 68.

${ }^{15}$ Jalaluddin Rakhmat, SQ For Kids.., h.79.'

${ }^{16}$ Akhmad Muzaimmin Azzet. Mengembangkan Kecerdasan.., h. 73.
} Dini, (Bandung: Mizan Pustaka, 2007), h. 78. 


\section{Irfani}

ISSN 1907-0969 E ISSN 2442-8272

Volume 16 Nomor 1 Juni 2020

Halaman 26-45

http://journal.iaingorontalo.ac.id/index.php/ir

\section{e. Mengunjungi saudara yang berduka}

1) Mengunjungi saudara yang sedang sakit

Kegiatan mengunjungi saudara kita yang sedang sakit ini memang bisa meningkatkan kecerdasan spiritual anak. Hal ini bisa terjadi karena anak akan tersentuh oleh keadaan yang sedang dialami oleh orang yang sedang sakit.

2) Mengunjungi saudara yang ditinggal mati

Mengajak anak mengunjungi saudara kita yang ditinggal mati agar anak mengerti bahwa mengunjungi saudara kita yang sedang ditinggal mati dapat menguatkan dan menghibur hati keluarga yang sedang ditinggal mati, kunjungan ini juga bisa membangkitkan kecerdasan spiritual anak. Kunjungan yang semacam ini bila dihayati dengan baik akan mengingatkan kita bahwa suatu saat kita pun akan mengalami kematian.

3) Mengunjungi saudara di makam

Kegiatan mengunjungi saudara di makam dikatakan juga bermanfaat untuk mencerdaskan spiritual karena dengan mengunjungi makam seseorang lebih mudah teringat terhadap kematian. Dengan mengingat kematian, seseorang akan menemukan banyak kesadaran di dalam jiwanya. ${ }^{17}$

f. Mengikutsertakan anak dalam kegiatan-kegiatan sosial

Kegiatan sosial ini bertujuan agar anak mengerti arti sebuah kebersamaan, kesetikawanan, kepedulian terhadap sesama sebagai makhluk ciptaan Tuhan, misalnya anak-anak diajak kerja bakti atau gotong royong, memberi bantuan kepada saudaranya yang tertimpa musibah dan lain-lain. ${ }^{18}$

g. Melatih sabar dan bersyukur

Agar anak-anak kita di masa depan dapat menghadapi persoalan dengan baik dan kehidupannya bisa bahagia, orang tua semestinya memberikan bimbingan kepada mereka. Bimbingan yang dapat kita berikan adalah melatihnya untuk bisa menjadi manusia yang mempunyai sifat sabar dan syukur, dua sifat tersebut dapat meningkatkan kecerdasan spiritual anak.

Tanpa kesabaran, seseorang akan sulit merasakan kebahagiaan. Sebab tidak semua yang direncanakan oleh manusia itu dapat berjalan dengan baik dan lancer.Tidak semua yang diinginkan oleh manusia itu dapat terpenuhi.Disinilah dibutuhkan sebuah kesabaran.

Selain sabar sifat yang dilatihkan kepada anak-anak yaitu sifat bersyukur. Sifat bersyukur ini penting karena tidak sedikit diantara kita yang selalu saja kita

\footnotetext{
${ }^{17}$ Akhmad Muzaimmin Azzet. Mengembangkan Kecerdasan.., h. 82.

${ }^{18}$ F itri Indriani, "Strategi Peningkatan Kecerdasan Spiritual Anak Di Sekolah Dasar", Universitas Muhammadiyah Surakarta, 2015, h. 108.
} 


\section{Irfani}

ISSN 1907-0969 E ISSN 2442-8272

Volume 16 Nomor 1 Juni 2020

Halaman 26-45

http://journal.iaingorontalo.ac.id/index.php/ir

mengeluh, padahal sudah mempunyai apayang kita inginkan. Bersyukur itu bisa melalui dua langkah, yakni bersyukur kepada Tuhan dan berterima kasih kepada sesame manusia. ${ }^{19}$

Beberapa langkah yang harus dilakukan orang tua dalam mensukseskan pendidikan spiritual bagi anak, yaitu:

1) Anak harus dibiasakan untuk memaknai setiap tindakannya dengan memahamka`n apa dan tujuannya dalam mengambil suatu tindakan.

2) Orang tua hendaknya memperkenalkan Al-Qur'an sebagai materi yang harus dikuasai.

3) Orang tua senantia memperdengarkan cerita atau kisah teladan yang mengandung nilai spiritualisme.

4) Orang tua sebaiknya melibatkan anak dalam kegiatan-kegiatan sosial dan keagamaan sehingga anak terbiasa dan terlatih mentalnya untuk memiliki ikatan batin dengan Tuhan.

5) Tegaskan kepada anak bahwa keikutsertaan anak dalam kegiatan sosial bukan untuk dilihat atau dipuji orang lain. Akan tetapi sebagai bentuk kepeduliaan dan kepekaan sosial yang hal itu sudah merupakan kewajiban dan kebutuhan rasa sosial setiap manusia. ${ }^{20}$

2. Media Pembelajaran Interaktif

Media menurut istilah yaitu bentuk jamak dari medium dan menurut harfiah adalah pengantar atau perantara. Menurut Association for Education and Communicati on Technology (AECT), Media adalah saluran atau berbagai rupa yang digunakan sebagai mode informasi. ${ }^{21}$ Miarso yang dikutip oleh Rudy Sumiharsono menyatakan bahwa media adalah berbagai bentuk objek sebagai penyalur suatu pesan kepada penerima sehingga mampu membangkitkan kemauan, pehatian serta fikiran siswa dalam belajar. ${ }^{22}$ Secara garis besar manusia, materi atau kejadian yang membangun kondisi yang membuat peserta didik mampu memperoleh pengetahuan, keterampilan, atau sikap merupakan media. ${ }^{23}$ Dipahami bahwa media adalah segala sesuatu yang berperan sebagai prantara

\footnotetext{
${ }^{19}$ Akhmad Muzaimmin Azzet. Mengembangkan Kecerdasan.., h. 84.

${ }^{20}$ Safrudin Aziz, Pendidikan Keluarga, Konsep dan Strategi, (Jakarta: Gava Media, 2015), h. 89

${ }^{21}$ Tejo Nurseto, "Membuat Media Pembelajaran yang Menarik," Jurnal Ekonomi dan Pendidikan 8, no. 1 (2011). 2017).

${ }^{22}$ Rudy Sumiharsono and Hisbiyatul Hasanah, Media Pembelajaran, (Pustaka Abadi,

23 Rostina Sundayana. Media Dan Alat Peraga Dalam Pembelajaran Matematika. (Bandung: Alfabeta, 2014), h. 4.
} 


\section{Irfani}

ISSN 1907-0969 E ISSN 2442-8272

Volume 16 Nomor 1 Juni 2020

Halaman 26-45

http://journal.iaingorontalo.ac.id/index.php/ir

untuk menyalurkan informasi yang bertujuan dapat merangsang pemikiran pelajar serta menarik pelajar untuk belajar.

Pembelajaran yaitu suatu proses yang kompleks, dimana terdapat dua subjek yaitu antara pelaku pelajar dan pembelajar. Pembelajaran berarti suatu bentuk timbal balik antara peserta didik, pendidik ataupun dengan lingkungannya yang dapat menumbuhkan motivasi agar peserta didik dapat berkembang baik secara mental ataupun intelektualnya. ${ }^{24}$ Pengertian lain yaitu suatu pembelajaran merupakan kegiatan interaksi diantara pengajar, bahan ajar dan pembelajaran, dengan tanpa bantuan fasilitas penyampai pesan tak akan berjalan. ${ }^{25}$ Dipahami pembelajaran yaitu suatu proses interaksi atara dua subjek yaitu pendidik dan pelajar yang bertujun untuk meningkatkan mental ataupun intelektual pelajar.

Media interaktif ialah penggabungan dari media digital tergolong kombinasi dari moving images, electronic text, sound, dan graphics menjadi golongan digital yang tersusun mampu membuat interaksi antara orang dengan data berdasarkan tujuan yang akurat. ${ }^{26}$ interaktif artinya berkaitan adanya interaksi dua arah. $^{27}$ Struktur media pembelajaran interaktif digunakan untuk mempermudah dalam perancangan yang dibangun. ${ }^{28}$

Media interaktif bisa digunakan sebagai media pendidikan yang dapat dihandalkan. Dibandingkan dengan media yang lain, media interaktif mempunyai berbagai kelebihan. Multimedia mampu merangkum berbagai media seperti media teks, suara, grafik gambar, dan animasi dalam satu sajian digital. multimedia interaktif adalah pemanfaatan computer untuk menggabungkan teks, grafik, audio, gambar bergerak (video dan animasi) menjadi satu kesatuan dengan link tool yang tepat sehingga memungkinkan pemakai multimedia dapat Melakukan navigasi, berinteraksi, berkreasi, dan berkomunikasi. $^{29}$

${ }^{24}$ Mukhlison Effendi, "Integrasi Pembelajaran Active Learning Dan Internet-Based Learning Dalam Meningkatkan Keaktifan Dan Kreativitas Belajar," Nadwa (7) 2 (2016), h, 283309.

${ }^{25}$ Rostina Sundayana, Media dan.., h. 5-6

26 Rudi Yulio Anandiono dan Nugrahadi Ramadhani, "Perancangan Media Pembelajaran Interaktif Matematika Untuk Siswa 5 DS", Jurnal Sains Dan Seni POMITS, 2.1 (2013), h. 2337-3520.

27 Rodiawati and Komarudin, "Pengembangan E-Learning Melalui Modul Interaktif Berbasis Learning Content Development System", h. 6.

28 Wawan Saputra and Bambang Eka Purnama, "Pengembangan Multimedia Pembelajaran Interaktif Untuk Mata Kuliah Organisasi Komputer," Speed - Sentra Penelitian Engineering Dan Edukasi 4, no. 2 (2015).

29 "View Of Peranan Media Pembelajaran Berbasis Multimedia Interaktif Berbantuan Macromedia Flash Sebagai Sumber Belajar Mandiri Untuk Meningkatkan Daya Ingat Dan Minat 


\section{Irfani}

ISSN 1907-0969 E ISSN 2442-8272

Volume 16 Nomor 1 Juni 2020

Halaman 26-45

http://journal.iaingorontalo.ac.id/index.php/ir

Dipahami bahwa, media interaktif adalah kombinasi dari media digital yang dapat menyebabkan terjadinya interaksi dua arah dimana perancangannya mempermudah untuk tujuan yang akurat. Berdasarkan penjelasan di atas, media pembelajaran interaktif merupakan suatu alat, bahan atau teknik berupa media digital yang dapat membuat orang berinteraksi dengan data guna memperoleh tujuan yang tepat, yang digunakan dalam kegiatan belajar mengajar yang bertujuan membuat pembelajaran menjadi menarik lagi dan lebih baik lagi.

Keuntungan dalam menggunakan media pembelajaran interaktif adalah kemampuan mengintegrasikan berupa teks, grafik, gambar animasi dan video. Hal ini menyebabkan kemampuan dalam menyampaikan informasi dan pengetahuan dengan tingkat realisme yang tinggi sehingga penggunaan bahan ajar menggunakan multimedia memungkinkan pengguna dapat berinteraksi dan berkomunikasi tanpa bantuan orang lain dan pengguna dapat mempelajari materi sesuai dengan kemampuannya masing-masing. Dalam proses belajar dapat meningkatkan hasil belajar dengan penggunaan waktu dan biaya yang relatif kecil. Contoh yang tepat untuk ini adalah program komputer simulasi untuk melakukan percobaan pada mata kuliah sains dan teknologi. Penggunaan program simulasi ini dapat mengurangi biaya bahan dan peralatan untuk melakukan percobaan. $^{30}$

Penerapan dan penggunaan kemajuan teknologi informasi dan multimedia dalam bidang pendidikan akan memberikan beberapa manfaat dalam proses pembelajaran, seperti: ${ }^{31}$

a. Sistem pembelajaran lebih inovatif dan interaktif. Pengajar akan selalu dituntut untuk kreatif inovatif dalam mencari terobosan pembelajaran.

b. Mampu menggabungkan antara teks, gambar, audio, musik, animasi gambar atau video dalam satu kesatuan yang saling mendukung guna tercapainya tujuan pembelajaran.

c. Membuat hal-hal yang abstrak menjadi konkret dan jelas. Penjelasan melalui multimedia (teks, gambar, animasi, maupun video) akan lebih mudah dipahami peserta didik jika dibandingkan dengan belajar dari buku teks saja.

Belajar Peserta Didik Pada Materi Jarak Dalam Ruang Untuk Sma Kelas XII," accessed March 3, 2020.

30 Muhammad Munir, "Pengembangan Media Pembelajaran Interaktif Kompetensi Dasar Register Berbasis Inkuiri Terbimbing," Jurnal Pendidikan Teknologi dan Kejuruan 22, no. 2 (October 1, 2014): 184-90.

31 Wanda Ramansyah, "Pengembangan Multimedia Pembelajaran Interaktif Dengan Tema Pengenalan Huruf Hijaiyah Untuk Peserta Didik Sekolah Dasar,” Edutic - Scientific Journal of Informatics Education 3, no. 1 (2016). 


\section{Irfani}

ISSN 1907-0969 E ISSN 2442-8272

Volume 16 Nomor 1 Juni 2020

Halaman 26-45

http://journal.iaingorontalo.ac.id/index.php/ir

d. Mampu menimbulkan rasa senang selama proses pembelajaran berlangsung. Hal ini akan menambah motivasi peserta didik selama proses pembelajaran hingga didapatkan tujuan pembelajaran yang maksimal.

3. Mata Pelajaran Aqidah Akhlak

Mata pelajaran akidah akhlak merupakan salah satu cabang dari pendidikan agama Islam. Pendidikan agama Islam merupakan suatu upaya yang dilakukan dengan tujuan untuk melakukan pembinaan dan pengasuhan terhadap peserta didik dalam memahami isi ajaran Islam. Kemudian setelah memahaminya peserta didik dapat mengaplikasikannya sebagai tolak ukur dalam kehidupan. ${ }^{32}$ Sehingga, output dari pendidikan agama Islam dengan tujuannya bisa difungsikan sebagai pandangan hidup seorang muslim.

Akidah ${ }^{33}$ merupakan dasar yang paling pokok dalam ajaran Islam, ${ }^{34}$ yakni keyakinan $^{35}$ mengesakan Allah. Keyakinan mengesakan Allah inilah yang menjadi tujuan besar bagi kerasulan nabi Muhammad saw. Mengesakan Allah ${ }^{36}$ adalah nilai dasar agama yang sesuai dengan akal dan rasio serta sesuai dengan ilmu pengetahuan. ${ }^{37}$ Esa dalam Kamus Besar Bahasa Indonesia berarti tunggal atau satu. Dalil bahwa Allah Esa dan tidak memiliki sekutu bisa dibuktikan dengan nalar maupun nash (aqli atau naqli). ${ }^{38}$

Sedangkan akhlak ${ }^{39}$ secara bahasa bermakna pembuatan atau penciptaan. Dalam konteks agama, akhlak bermakna perangai, budi, tabi'at, adab, atau tingkah laku. ${ }^{40}$ Ini sesuai dengan Kamus Besar Bahasa Indonesia, kata akhlak

32 Abdul Majid dan Dian Andriani, Pendidikan Agama Islam Berbasis Kompetensi (Konsep Implementasi Kurikulum 2004), (Bandung, Remaja Rosdakarya, 2005), h. 130.

${ }^{33}$ Secara etimologi akidah berarti ikatan. Lihat Taufik Yumansyah, Buku Akidah Akhlak (Jakarta: Grafindo Media, 2008), cet. 1, h. 3. Lihat juga Mahmud Yunus, Kamus Arab-Indonesia (Jakarta: PT Hiidakarya Agung, 1972) h. 274. Lihat juga Idrus Alkaf, Kamus 3 Bahasa Al-Manar (Surabaya: Karya Utama, 2005), h. 594.

${ }^{34}$ Muhammad 'Imaduddin Abdulrahim, Kuliah Tauhid, (Bogor: Pustaka, 1982), cet. 3, h. 1 .

h. 87 .

${ }^{35}$ Ahmad Warson Munawir, Kamus Al-Munawir (Yogyakarta: Pustaka progresif, 1989),

${ }^{36}$ Aminuddin, dkk, Pendidikan Agama Islam (Bogor: Ghalian Indonesia, 2005), h. 81.

37 Tarmizi Taher, Menyegarkan Akidah Tauhid Insani: Mati di Era Klenik, (Jakarta: Gema Insani Press, 2002), cet. 1, h. 55.

${ }^{38}$ Fauzi Faishal Bahreisy, Terjemahan Dari Al-Qashid al-Mujarrad fi Ma'rifat al-Ism al-Mufrod Karya Ibnu 'Atho'illah al-Iskandary, (Jakarta: Zaman, 2013), cet. 1, h. 115.

${ }^{39}$ Islam sangat serat dengan akhlak, karena pada subtansinya ajaran Islam tidak bisa dijauhkan dari nilai-nilai tauhid dan humanis. Lihat Muhammad Abdurrahman, Bagaimana Seharusnya berakhlak Mulia (Aceh: Adnin Foundation, 2014), h. 6.

${ }^{40}$ Ahmad Bangun Nasution dan Rohani Hanun Siregar, Akhlak Tasawuf Pengenalan, Pemahaman,dan Pengaplikasiannya (disertai biografi tokoh-tokoh sufi), (Jakarta: PT. Rajagrafindo Persada, 2013), cet. 1, h. 30. Lihat juga Muhammad Daud Ali, Pendidikan Agama 


\section{Irfani}

ISSN 1907-0969 E ISSN 2442-8272

Volume 16 Nomor 1 Juni 2020

Halaman 26-45

http://journal.iaingorontalo.ac.id/index.php/ir

diartikan sebagai budi pekerti, watak, tabi'at. ${ }^{41}$ Adapun yang dimaksud dengan akhlak adalah sebuah sistem lengkap yang terdiri dari karakteristik-karakteristik akal atau tingkah laku yang membuat seseorang menjadi istimewa. ${ }^{42}$

Terkait dengan akidah dan akhlak, adapun beberapa unsur yang dapat dikembangkan. Hal tersebut sangat serat dengan moral dan budaya sekaligus latar belakang sosial seorang peserta didik tinggal. Pembelajaran moral lebih ideal ketika disesaikan dengan kebutuhan peserta didik, artinya setiap peserta didik memiliki karakter yang berbeda-beda. Sehingga, dalam memasukan unsur-unsur dalam akidah akhlak khususnya terkait dengan unsur moral berisi, nalar moral, rasa, tindakan moral dan perihal keimanan. ${ }^{43}$

Akidah akhlak yang benar tidak menafikan fitrah manusia yang diberikan Tuhan, yakni eksistensi akal. Namun, dalam hal in yang menjadi sumber baik buruknya, benar salahnya yang utama ialah teks-teks agama yakni al-Qur'an hadist. ${ }^{44}$ Adapun mata pelajaran akidah akhlak yang dimaksud ialah akidah akhlak untuk jenjang Madrasah Tsanawiyah (MTs).

Mata pelajaran akidah akhlak memiliki tujuan menunjukan dan meningkatkan keimanan siswa, sehingga dapat dioutputkan ke dalam bentuk aplikasi kehidupan sosial. Adapun implikasinya terhadap perilaku individu sebagai manusia beragama yakni teraplikasikannya perilaku terpuji melalui pembelajaran dan pemahaman melalui pencarian pengetahuan, kemudian menghayatinya, sehingga memberikan pengalaman kepada peserta didik terkait akidah dan akhlak. Selain itu, visi dari mata pelajaran akidah akhlak ialah mebentuk muslim yang berkembang dan memiliki kualitas iman juga taqwa kepada Pencipta, sehingga berdampak dalam menjalankan kehidupan bermasyarakat, berbangsa dan bernegara sekaligus pandangan hidup panjang untuk masa panjang besok.

Ruang lingkup atau obyek kajian ilmu tauhid mencakup 3 bidang sebagai berikut:

a. Uluhuhiyat (masalah Ketuhanan), atau biasa disebut dengan ma'rifat al mabda'.

Islam (Jakarta: PT Raja Grafindo Persada, 2000), p. 199. Lihat juga Zahruddin dan Hasanudin Sinaga, Pengantar Studi Akhlak (Jakarta: PT Raja Grafindo Persada, 2004), h. 1.

${ }^{41}$ W.J.S. Poerwadarminta, Kamus Umum Bahasa Indonesia, (Jakarta: 1985), h. 25

${ }^{42}$ Abdul Hayyi al-Kattani, Terjemahan Dari at-Tarbiyah al-Islamiyah karya Ali Abdul Halim Mahmud, (Jakarta: Gema Insani, 2004), cet. 1, h. 26-27.

${ }^{43}$ Asri Budiningsih, Pembelajaran Moral (Jakarta: Asdi Mahasatya, 2004), h. 10.

${ }^{44}$ Abdul Majid dan Dian Andriani, Pendidikan Agama.., h. 67. 


\section{Irfani}

ISSN 1907-0969 E ISSN 2442-8272

Volume 16 Nomor 1 Juni 2020

Halaman 26-45

http://journal.iaingorontalo.ac.id/index.php/ir

Dalam obyek uluhiyyat yang menjadi bahasan pokok adalah Dzat, sifat, dan af'al dari Tuhan. Melalui uluhiyyat Allah mengutus Rasul-rasulNya untuk menyampaikan wahnyuNya kepada umat manusia dan meninggalkan segala yang menyesatkan hidup manusia, sperti menyembah berhala atau patung, ingkar atau ateis. Untuk itulah seruan pertama setiap risalah adalah untuk menyembah Tuhan. $^{45}$

b. Nubuwwah (masalah kenabian), atau biasa disebut dengan qism nubuwwat atau ma'rifat wasithah.

Kata nubuwwat berasal dari kata naba' yang berarti khabar (berita). Kata ini meiliki makna erat dengan kata nabi, sebagai seorang manusia yang diberi wahyu oleh Tuhan, dalam nubuwwat didalamnya membahas mengenai dzat, sifat dan af'alnya dari para Rasul dan Nabi. ${ }^{46}$

c. Sam'iyyat (masalah yang diberitakan), atau biasa disebut dengan qism sam'iyyat atau ma'rifat ma'ad.

Dalam sam'iyyat ini membahas apa saja yang dibawa Rasulullah baik dari pendengarannya maupun dari ucapannya. Termasuk di dalamnya seperti alam barzah, siksa kubur, hari kiamat, dan lain sebagainya. ${ }^{47}$

Apabila dijabarkan secara umum, maka kajian-kajian itu terangkum dalam rukun iman. ${ }^{48}$ Sedangkan, ruang lingkup akhak ialah sebagai berikut:

Adapun menurut Abuddin Nata bahwa ruang lingkup akhlak ialah sama dengan ajaran Islam itu sendiri. Khususnya yang berkaitan dengan pola hubungan. Akhlak Islami mecakup berbagai aspek, dimulai dari akhlak terhadap Allah, hingga kepada sesama makhluk. Antara lain sebagai berikut:

a. Akhlak Terhadap Allah

Akhlak terhadap Allah dapat diartikan sebagai sikap atau perbuatan yang seharusnya dilakukan oleh manusia sebagai makhluk kepada Penciptanya. ${ }^{49}$ Dalam hal ini, berkenaan dengan akhlak kepada Allah dilakukan dengan cara memuji-Nya, yakni menjadikan Tuhan sebagai satu-satunya yang menguasai dirinya. Oleh sebab itu, sebagai hamba Allah manusia mempunyai cara-cara untuk mendekatkan diri kepada Allah.

b. Akhlak Terhadap Makhluk

${ }^{45}$ Syahrin Harahap dan Hasan Bakti Nasution, Ensiklopedi Aqidah Islam, (Jakarta: Prenada Media, 2003), h. 449.

${ }^{46}$ Syahrin Harahap dan Hasan Bakti Nasution, Eksiklopedia Aqidah ..., h. 312.

${ }^{47}$ Syahrin Harahap dan Hasan Bakti Nasution, Eksiklopedia Aqidah ..., h. 369-370.

${ }^{48}$ Syahrin Harahap dan Hasan Bakti Nasution, Eksiklopedia Aqidah ..., h. 431.

${ }^{49}$ Abuddin Nata, Akhlak Tasawuf, (Jakarta: PT. RajaGrafindo Persada, 2012), cet. 2, h. 149. 


\section{Irfani}

ISSN 1907-0969 E ISSN 2442-8272

Volume 16 Nomor 1 Juni 2020

Halaman 26-45

http://journal.iaingorontalo.ac.id/index.php/ir

Alam diciptakan untuk kepentingan manusia sebagai sarana mutlak bagi pelaksaan misi tugasnya. ${ }^{50}$ Kedudukan manusia di alam raya ini disamping sebagai khalifah juga sekaligus sebagai hamba. Dengan pandangan terpadu ini, maka seorang khalifah tidak akan berbuat sesuatu yang dilarang oleh Allah. Dan untuk melaksanakan fungsi kekhalifahan yang baik, manusia perlu diberikan pengajaran, terutama tentang ketauhidan. ${ }^{51}$

Dalam al-Quran menyebutkan bahwa manusia atau Bani Adam sungguh telah dimuliakan oleh Allah dari makhluk lainnya. Itu berarti alam diciptakan lebih rendah dari manusia, harkat dan martabat manusia lebih tinggi dari alam. Adapun logika dari doktrin taskhir adalah bahwa:

a. Manusia adalah puncak tertinggi dari ciptaan Allah dan manusia adalah makhluk yang paling mulia disbanding dengan makhluk yang lain.

b. Alam dengan segala macam isinya diciptakan oleh allah pada posisi lebih rendah di bawah manusia.

c. Oleh sebab itu diciptakannya alam adalah untuk objek yang akan dimanfaatkan oleh manusia dengan sebesar-besarnya pemanfaatan.

d. Dengan demikian alam terbuka untuk dieksploitasi untuk kesejahteraan hidup makhluk termulia yakni manusia.

Oleh sebab itu, manifestasi iman dalam kekhalifahan pengelolaan alam, haruslah disadari bahwa perbuatan yang paling merusak martabat dan harkat manusia itu adalah bila manusia menempatkan alam berada lebih tinggi dari harkat dan martabat manusia itu sendiri dengan jalan mempertuhankan alam. ${ }^{52}$

B. Peningkatan Spiritualitas Melalui Media Pembelajaran Interaktif Pada Mata Pelajaran Aqidah Akhlak

Mata pelajaran akidah akhlak sangat serat dengan nilai-nilai spiritualitas. Hal ini diperkuat dengan ruang lingkupnya yang kental dengan normativitas dan lazimnya diajarkan menggunakan cara tradisional. Meskipun berada di zaman yang telah berkembang dan berbagai kecanggihan teknologi, terkadang masih banyak pada pendidik tidak memfungsikan kecanggihan teknologi yang telah tersedia. Hal tersebut menjadi polemik, ketika seorang anak yang menjadi peserta didik telah memfungsikan dan mendayakan ketersediaan teknologi sebagai alat

${ }^{50}$ Ahmad Syafii Maarif, Membumikan Islam (Yogyakarta: Pustaka Pelajar, 1995), cet. II, h. 12 .

${ }^{51}$ Abuddin Nata, Filsafat Pendidikan Islam, (Jakarta: Logos Wacana Ilmu, 1997), cet. 1, h. 40-41.

${ }^{52}$ Yunan Yusuf, Alam Pikiran Islam Pemikiran Islam: Dari Khawarij ke Buya HAMKA Hingga Hasan Hanafi, (Jakarta: Prenadamedia Group, 2014), cet. 1, h. 30-31. 


\section{Irfani}

ISSN 1907-0969 E ISSN 2442-8272

Volume 16 Nomor 1 Juni 2020

Halaman 26-45

http://journal.iaingorontalo.ac.id/index.php/ir

untuk memudahkannya dalam belajar. Sehingga, perlu difungsikan cara baru dalam pembelajaran

Dalam hal ini, pendidik perlu mendayakan teknologi sebagai alat atau media dalam pembelajaran, terkhusus pada mata pelajaran akidah akhlak, karena dalam konstruk yang telah diwariskan oleh tradisi, lazimnya pembelajaran terkait keagamaan masih kokoh menggunakan cara tradisional dalam menyampaikan suatu ilmu. Sehingga, membentuk pola pikir peserta didik bahwa pembelajaran keagamaan membosankan dan berimplikasi kemunduran akan pentingnya pembelajaran keagamaan yang berperngaruh pada spiritualitas mereka dalam memahami ilmu agama.

Berkaitan dengan hal tersebut, seorang pendidik perlu merubah suasana pembelajaran dengan mendayakan teknologi dalam mata pelajaran akidah akhlak yakni menerapkan media interaktif dalam suasana kelas. Dapat dipahami bahwa media adalah segala sesuatu yang berperan sebagai prantara untuk menyalurkan informasi yang bertujuan dapat merangsang pemikiran pelajar serta menarik pelajar untuk belajar. Adapun media interaktif ialah penggabungan dari media digital tergolong kombinasi dari moving images, electronic text, sound, dan graphics menjadi golongan digital yang tersusun mampu membuat interaksi antara orang dengan data berdasarkan tujuan yang akurat. Adapun fungsinya dalam pendidikan yakni:

Yang pertama, sebagai upaya untuk mengubah sistem pembelajaran yang lebih inovatif dan interaktif. Pengajar akan selalu dituntut untuk kreatif inovatif dalam mencari terobosan pembelajaran. Dalam hal ini, bisa membuat anak menjauhi rsa bosan dan lebih terfokus, terkhusus saat mengikuti pembelajaran keislaman. Sehingga, peserta didik mampu mengendalikan dirinya untuk lebih fokus dengan variasi pembelajaran yang diberikan pendidik. Hal ini berdampak pada pola pikir peserta didik tentang keislaman, khususnya terkait pandangannya tentang pembelajaran Islam yang membosankan dan kaku dengan metodenya yang tidak fleksibel atau tidak viariatif.

Yang kedua, media interaktif mampu menggabungkan antara teks, gambar, audio, musik, animasi gambar atau video dalam satu kesatuan yang saling mendukung guna tercapainya tujuan pembelajaran. Berkaitan dengan merelasikan atau mencocokan suatu perihal, hal ini terkait dengan cara pandang peserta didik akan pentinngnya mendayakan akal dengan maksimal dan mendayakan teks-teks suci secara maksimal. Bukan itu saja, hal ini juga melatih peserta didik menjadi generasi yang mampu memahami peningnya pemahaman akan teks-teks suci dengan memaksimalkan penggunaan akal kemudian mengaplikasikannya dalam 


\section{Irfani}

ISSN 1907-0969 E ISSN 2442-8272

Volume 16 Nomor 1 Juni 2020

Halaman 26-45

http://journal.iaingorontalo.ac.id/index.php/ir

kancah kehidupan beragama. Sehingga, membentuk moral spiritualitas pada pola pikir dan bentuk tindakan.

Yang ketiga, membuat hal-hal yang abstrak menjadi konkret dan jelas, artinya eksistensi media interaktif dalam pembelajaran akidah akhlak ikut serta dalam meningkatkan mutu spiritual peserta didik melalui penjelasan lebih konkret atas berbagai hal berbau agama. Hal ini melatih kecerdasan spiritual seorang siswa dalam menemukan poin-poin dalam pembelajaran, artinya pendidik memberikan penjelasan singkat dan jelas menggunakan media yang ada dan melkukan interaksi dua arah antara murid dan guru. Sehingga, peserta didik mampu menemukan titik poin yang menjadi fokus pembahasan dalam pembelajaran. Hal ini juga berdampak pada pandangan peserta didik terhadap suatu hal, termasuk ibadah.

Yang ke-empat, mampu menimbulkan rasa senang selama proses pembelajaran berlangsung terhadap peserta didik. Dalam hal ini, media interaktif dengan kekhasan yang khas yakni variatif dalam model pembelajaran, inovatif, dan jelas memberikan ketenangan pada peserta didik. Sehingga, dari ketenangan tersebut bertransformasi menuju pada kesenangan akan keislaman. Dengan demikian, memberikan sumbangsih berupa peningkatan spiritualitas peserta didik sebagai alat bantu dalam pembelajaran.

Dari kempat fungsi media pembelajaran interkatif yang difungsikan dalam mata pelajaran akidah akhlak membentuk paradigma peserta didik yang berawal dari perubahan pandangan bahwa pembelajaran agama merupakan pembelajaran yang menyenangkan. Selain itu, pelajaran agama juga pelajaran yang tidak mengesampingkan perkembangan teknologi. Hal ini terlihat dalam model pembelajarannya yang mulai dimasuki oleh kecanggihan teknologi. Sehingga, dari media interaktif tersebut memberikan sumbangsih pandangan peserta didik terhadap pembelajaran keagamaan.

Bukan itu saja, peningkatan spiritualitas yang hadir disebabkan oleh masuknya modernitas dalam pembelajaran yakni berupa media sebagai sarana membentuk sikap peserta didik yang aktif. Hal tersebut dikarenakan dalam media interaktif yang menjadi pusat pembelajaran tidak selalu guru, melainkan juga siswa. Sehingga, siswa harus ikut aktif dalam pembelajaran keagamaan dengan tujaun membentuk mental.

Berubahnya pola pikir atau pandangan peserta didik terhadap pembelajaran keagamaan sekaligus isinya, sehingga merambat pada wilayah sikap aktif siswa dengan tuntutan harus aktif dalam pembelajaran yang tidak menjadikan guru sebagai pusat pembelajaran secara terus-menerus seperti yang 


\section{Irfani}

ISSN 1907-0969 E ISSN 2442-8272

Volume 16 Nomor 1 Juni 2020

Halaman 26-45

http://journal.iaingorontalo.ac.id/index.php/ir

telah diwariskan oleh tradisi. Dari kedua hal tersebut, membentuk kebiasaan yang kental dengan spiritualitas dengan sasaran pola pikir, sikap dan kebiasaan. Sehingga, media pembelajaran yang interaktif memberikan sumbangsih luar biasa dalam pembalajaran terkhusus dalam meningkatkan spiritualitas anak dalam mata pelajaran akidah akhlak.

\section{KESIMPULAN}

Penggunaan media pembelajaran interaktif dalam pembelajaran akidah akhlak dapat meningkatkan spiritualitas siswa. Hal ini dikarenakan, dalam pembelajaran interaktif peserta didik tidak hanya menjadi objek pasif melainkan juga aktif, sehingga mentalnya terdidik dan percaya diri tumbuh melalui keharusan ikut aktif dalam interaksi dikelas, terkhusus pada mata pelajaran yang serat dengan ketuhanan dan kemanusiaan yakni akidah akhlak.

Peningkatan spiritualitas peserta didik diawali dengan berubahnya pola pikir atau pandangan peserta didik terhadap pembelajaran keagamaan sekaligus isinya, sehingga merambat pada wilayah sikap aktif siswa dengan tuntutan harus aktif dalam pembelajaran yang tidak menjadikan guru sebagai pusat pembelajaran secara terus-menerus seperti yang telah diwariskan oleh tradisi. Dari kedua hal tersebut, membentuk kebiasaan yang kental dengan spiritualitas dengan sasaran pola pikir, sikap dan kebiasaan. Sehingga, media pembelajaran yang interaktif memberikan sumbangsih luar biasa dalam pembalajaran terkhusus dalam meningkatkan spiritualitas anak dalam mata pelajaran akidah akhlak.

\section{DAFTAR PUSTAKA}

Abdul Majid dan Dian Andriani, 2005. Pendidikan Agama Islam Berbasis Kompetensi (Konsep Implementasi Kurikulum 2004), Bandung, Remaja Rosdakarya.

Abuddin Nata, 2012. Akhlak Tasawuf, Jakarta: PT. RajaGrafindo Persada.

Abuddin Nata, 1997. Filsafat Pendidikan Islam, Jakarta: Logos Wacana Ilmu.

Abdul Hayyi al-Kattani, 2004. Terjemahan Dari at- Tarbiyah al-Islamiyah karya Ali Abdul Halim Mahmud, Jakarta: Gema Insani.

Agus Efendi, 2005. Revolusi Kecerdasan Abad, Bandung, Alfa Beta.

Ahmad Warson Munawir, 1989. Kamus Al-Munawir, Yogyakarta: Pustaka progresif. 


\section{Irfani}

ISSN 1907-0969 E ISSN 2442-8272

Volume 16 Nomor 1 Juni 2020

Halaman 26-45

http://journal.iaingorontalo.ac.id/index.php/ir

Ahmad Syafii Maarif, 1995. Membumikan Islam, Yogyakarta: Pustaka Pelajar.

Ahmad Bangun Nasution dan Rohani Hanun Siregar, 2013. Akhlak Tasawuf Pengenalan, Pemahaman,dan Pengaplikasiannya (disertai biografi tokohtokoh sufi), Jakarta: PT. Rajagrafindo Persada.

Akhmad Muzaimmin Azzet. 2013. Mengembangkan Kecerdasan Spiritual Bagi Anak, Yogyakarta: Katahati.

Aminuddin, dkk, 2005. Pendidikan Agama Islam, Bogor: Ghalian Indonesia.

Ariwibowo Suprajitno A \& Irianti E, 2010. Menyentuh Hati Menyapa Tuhan (Renungan dan Kebiasaan menuju Kecerdasan Spiritual), Jakarta: Elex Medina Komputindo.

Asri Budiningsih, 2004. Pembelajaran Moral, Jakarta: Asdi Mahasatya.

Baharudin, 2005. Aktualisasi Psikologi Islami, Yogyakarta: Pustaka Pelajar.

Effendi, Mukhlison. "Integrasi Pembelajaran Active Learning Dan Internet-Based Learning Dalam Meningkatkan Keaktifan Dan Kreativitas Belajar.” Nadwa 7, no. 2 (March 22, 2016).

Fauzi Faishal Bahreisy, 2013. Terjemahan Dari Al-Qashid al-Mujarrad fi Ma'rifat al-Ism al-Mufrod Karya Ibnu 'Atho'illah al-Iskandary, Jakarta: Zaman.

Fitri Indriani, 2015. "Strategi Peningkatan Kecerdasan Spiritual Anak Di Sekolah Dasar", Universitas Muhammadiyah Surakarta.

Heri Gunawan, 2014. Pendidikan Isalm. Bandung: Remaja Rosdakarya.

Idrus Alkaf, 2005. Kamus 3 Bahasa Al-Manar, Surabaya: Karya Utama.

Izzatul Mufidah, Chilmiyah. "Pengembangan Modul Pembelajaran Pada Kompetensi Dasar Hubungan Masyarakat Kelas X Apk 2 Di Smkn 10 Surabaya." Jurnal Pendidikan Administrasi Perkantoran (JPAP) 2, no. 2 (August 26, 2014).

Jalaluddin Rakhmat, 2007. SQ For Kids: Mengembangkan Kecerdasan Spiritual Anak Sejak Dini, Bandung: Mizan Pustaka. 


\section{Irfani}

ISSN 1907-0969 E ISSN 2442-8272

Volume 16 Nomor 1 Juni 2020

Halaman 26-45

http://journal.iaingorontalo.ac.id/index.php/ir

Latuconsina, Hudaya. 2014. Pendidikan Kreatif: Menuju Generasi Kreatif dan Kemajuan Ekonomi Kreatif di Indonesia. Jakarta: Gramedia Pustaka Utama.

Mahmud Yunus, 2005. Kamus Arab-Indonesia, Jakarta: PT Hiidakarya Agung.

Muhammad Daud Ali, 2000. Pendidikan Agama Islam, Jakarta: PT Raja Grafindo Persada.

Muhammad 'Imaduddin Abdulrahim, 1982. Kuliah Tauhid, Bogor: Pustaka.

Muhammad Muntahibun Nafis, 2011. Ilmu Pendidikan Islam. Yogyakarta: Teras.

Muhammad Syazali Rubhan Masykur, Novrizal, 2017. "Pengembangan Media

Muhammad Abdurrahman, 2014. Bagaimana Seharusnya berakhlak Mulia, Aceh: Adnin Foundation.

Munir, Muhammad. 2014. "Pengembangan Media Pembelajaran Interaktif Kompetensi Dasar Register Berbasis Inkuiri Terbimbing." Jurnal Pendidikan Teknologi dan Kejuruan 22, no. 2.

Nurseto, Tejo. 2011. "Membuat Media Pembelajaran yang Menarik." Jurnal Ekonomi dan Pendidikan 8, no. 1.

Pembelajaran Matematika Dengan Macromedia Flash ${ }^{\text {ee }}$ Al-Jabar: Jurnal Pendidikan Matematika, 8.2.

Ramansyah, Wanda. 2016. "Pengembangan Multimedia Pembelajaran Interaktif Dengan Tema Pengenalan Huruf Hijaiyah Untuk Peserta Didik Sekolah Dasar." Edutic - Scientific Journal Of Informatics Education 3, No. 1.

Rodiawati, Heni, And Komarudin Komarudin. 2018. "Pengembangan E-Learning Melalui Modul Interaktif Berbasis Learning Content Development System." Jurnal Tatsqif 16, No. 2.

Rudi Yulio Anandiono dan Nugrahadi Ramadhani, 2013. "Perancangan Media Pembelajaran Interaktif Matematika Untuk Siswa 5 DS", Jurnal Sains Dan Seni POMITS, 2.1. 


\section{Irfani}

ISSN 1907-0969 E ISSN 2442-8272

Volume 16 Nomor 1 Juni 2020

Halaman 26-45

http://journal.iaingorontalo.ac.id/index.php/ir

Saputra, Wawan, and Bambang Eka Purnama. 2011. "Pengembangan Multimedia Pembelajaran Interaktif Untuk Mata Kuliah Organisasi Komputer.” Speed Sentra Penelitian Engineering Dan Edukasi 4, no. 2.

Safrudin Aziz, 2015. Pendidikan Keluarga, Konsep dan Strategi, Jakarta: Gava Media.

Syahrin Harahap dan Hasan Bakti Nasution, 2003. Ensiklopedi Aqidah Islam, Jakarta: Prenada Media.

Sumiharsono, Rudy, and Hisbiyatul Hasanah. 2017. Media Pembelajaran: Buku Bacaan Wajib Dosen, Guru dan Calon Pendidik. Pustaka Abadi.

Tarmizi Taher, 2002. Menyegarkan Akidah Tauhid Insani: Mati di Era Klenik, Jakarta: Gema Insani Press.

Taufik Yumansyah, 2008. Buku Akidah Akhlak, Jakarta: Grafindo Media.

Ujam Jaenudin, 2012. Psikologi Transpersonal, Bandung: Pustaka Setia.

"View Of Peranan Media Pembelajaran Berbasis Multimedia Interaktif Berbantuan Macromedia Flash Sebagai Sumber Belajar Mandiri Untuk Meningkatkan Daya Ingat Dan Minat Belajar Peserta Didik Pada Materi Jarak Dalam Ruang Untuk Sma Kelas Xii.” Accessed March 3, 2020.

Wahyudi Siswanto, 2010. Membentuk Kecerdasan Spiritual Anak. Jakarta: Hamzah.

W.J.S. Poerwadarminta, 1985. Kamus Umum Bahasa Indonesia, Jakarta.

Yunan Yusuf, 2014. Alam Pikiran Islam Pemikiran Islam: Dari Khawarij ke Buya HAMKA Hingga Hasan Hanafi, Jakarta: Prenadamedia Group.

Zahruddin dan Hasanudin Sinaga, 2004. Pengantar Studi Akhlak, Jakarta: PT Raja Grafindo Persada. 